\title{
The Exploration of Kolok Students' of Mathematics Ability in Inclusive Education at SD Negeri 2 Bengkala Kubutambahan District
}

\author{
I Made Suarjana $^{1 *}$ \\ ${ }^{1}$ Primary School Teacher Education Study Program, Faculty of Education, Universitas Pendidikan Ganesha, \\ Singaraja 81116, Indonesia \\ *Corresponding author. Email: imade.suarjana@undiksha.ac.id
}

\begin{abstract}
The research objectives were (1) to describe the ability of Kolok students to learn mathematics; (2) describe the normal role of students in helping kolok students; and (3) describe the role of parents / family in helping kolok students learn mathematics. The research subjects were 3 grade VI students who were kolok (speech impaired) at SD Negeri 2 Bengkala, Kubutambahan. This research is a phenomenological study emphasizing the meaning of experience for a number of individuals, focused on the abstract analysis schema of a phenomenon related to a special situation. To determine the ability of kolok students in mathematics, especially arithmetic, data were collected by means of tests. To determine the normal role of students in helping kolok students learn mathematics, data were collected using the observation method. To find out the parenting styles of students' parents / families in helping kolok students in learning mathematics, data were collected using observation and interview methods. Data analysis was performed with descriptive statistics to describe the object under study, data exploration, and to describe all information that supports the research results. The results showed that (1) the mathematical abilities of kolok students in mathematics, especially arithmetic, were still lacking, (2) collaboration between normal students and kolok students in online learning was lacking, and (3) the role of parents / families in helping kolok students learn mathematics at home are severely lacking due to their limitations in technological abilities and mathematical abilities.
\end{abstract}

Keywords: Exploration, Inclusive Education, Mathematics

\section{INTRODUCTION}

Currently, the kolok (speech impaired) is estimated to reach 42 out of 2275 residents in Bengkala Village, Kubutambahan District. This number includes nine families with deaf and mute disorders. This is a quite high number, considering that normally congenital deafness only occurs in one in 10 thousand births. In daily communication, kolok people use sign language, and according to the statement of the Bengkala Village Chief, all Bengkala residents know sign language, regardless of whether they are deaf mute or not. Uniquely, those who are not kolok, even though they are fluent in speaking, prefer to use sign language. Unlike the international standard sign language in communication for the deaf and speech impaired, the sign language of kolok is much simpler and can be learned in a relatively short time. For example, the kolok sign language for eating is pointing the fingers towards the mouth and holding the stomach when hungry. In addition, moving the tip of the index finger as a male meaning and linking the tip of the index finger with the tip of the middle finger in a circle for women.

Children with DLD typically struggle with learning in school; however, the mechanism by which DLD impacts academic success is unclear. Mathematics involves demands in the multiple domains and therefore holds potential for examining the relationship between language and academic performance on tasks mediated by verbal and nonverbal demands [1]. As of July 192007 , SD Negeri 2 Bengkala began to hold inclusive education as a form of concern for the education of children with special needs in Bengkala Village. The idea of organizing inclusive education at SD Negeri 2 Bengkala originated from the school's concern about the education of deaf children with mute in Bengkala Village. The school wants learning together between deaf students and 
normal students. The school feels compelled to see deaf children who are mute so they can get an education like normal children. Students who are deaf or hard of hearing experience delayed language acquisition, which affects their capacity to solve arithmetic word problems [2]. Until now, the education of deaf and mute children in Bengkala Village has been going well. In fact, all deaf and mute children in Bengkala Village have received proper education. The results of preliminary observations at SD Negeri 2 Bengkala obtained the following results: (1) SD Negeri 2 Bengkala is a school that provides inclusive education, (2) the learning process carried out in the classroom usually has 1 homeroom teacher and 1 special teacher who helps students deaf and speech impaired in the learning process in the classroom. Learning in the classroom is carried out simultaneously with other normal students, (3) there are fewer problems or difficulties in communicating between mute and deaf students with normal students in learning at school, (4) normal student social interaction with deaf and mute children activities at school go well, as does student interaction in general, and (5) the pattern of inclusive education at SD Negeri 2 Bengkala is that children with special needs are combined in regular classes. To detect the nature of the difficulties children with specific language impairment (SLI) exhibited in mathematics, the first-and second-grade children's performance was compared to mental age and language age comparison groups of typically developing children on a series of tasks that examined conceptual, procedural, and declarative knowledge of mathematics [3]. At certain times children with special needs are specially mentored by the students with special needs' teacher in a separate class. As shown in the following picture.

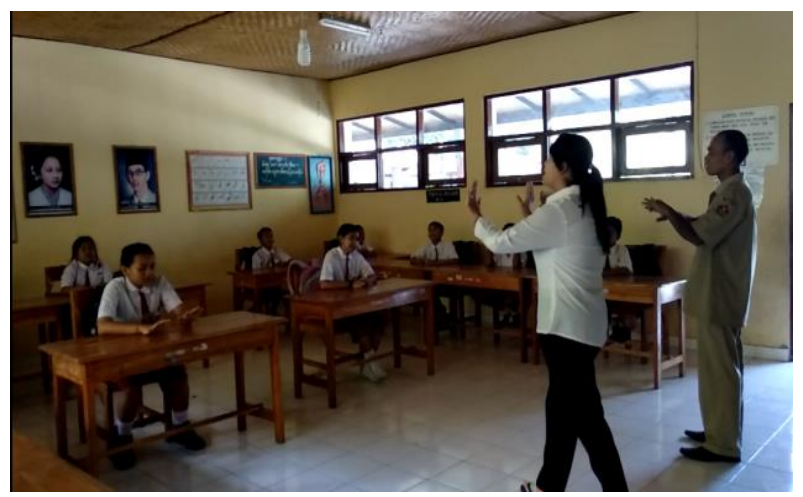

Figure 1 Children with special needs joining the regular class are supervised by two teachers.

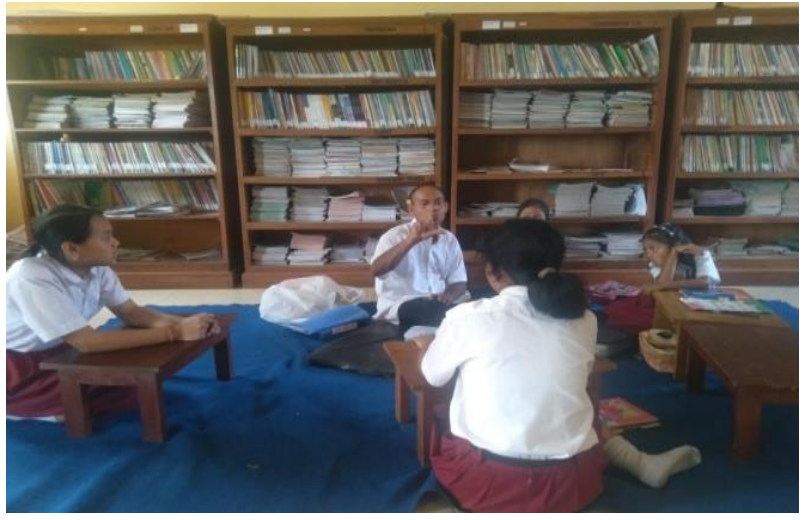

Figure 2 Guidance for children with special needs in special classes.

Referring to the description of inclusive education and normal education, it is necessary to conduct research related to the ability of deaf and mute students or kolok students in learning mathematics. Learning mathematics, especially in inclusive education, certainly has a different approach compared to normal schools. In accordance with Regulation of The Minister of National Education number 70 of 2009 , the local government needs to prepare schools for inclusive education so that children with special needs have the opportunity to learn and optimize their potential. There are several models that can be applied in inclusive education, one of which needs to be done is that the mainstreaming model is a model that combines children with special needs and general education. Children with special needs are combined with regular class children for some time [4]. This is in accordance with the service options, including the form of regular classes with pull out. In this activity children with special needs study together with normal children in regular classes but at certain times are pulled from the regular class to a special room to study under a special supervisor.

The implementation of inclusive education certainly creates problems for students in learning mathematics. The results of the research [5] that is, even though there are students with special needs, teachers have never labeled students as troublesome. All students are given the same opportunity to take part in special activities in class. The government is obliged to prepare schools to provide inclusive education. There are many obstacles experienced by teachers in learning students with special needs. The learning pattern carried out in inclusive education at SD Negeri 2 Bengkala is classical and small group learning. Likewise, mathematics has its own characteristics in learning. Therefore, it is necessary to conduct research with the aim of (1) describing the ability of Kolok students to learn mathematics; (2) describe the normal role of students in helping kolok students; and (3) describe the role of parents / family in helping kolok students learn mathematics. 


\section{RESEARCH METHODS}

This research is a basic research with a phenomenological study emphasizing the meaning of experience for a number of individuals, focused on developing theories to produce theory, abstract analysis schemes of phenomena related to specific situations [6]. The subjects of this study were students with special needs in SD Negeri 2 Bengkala, Kubutambahan. The process of collecting data uses the constant comparative method by digging up information and comparing it with the emerging categories [6]. To describe the ability of kolok students in learning mathematics, data were collected by means of tests. To describe the role of normal students in helping kolok students learn mathematics, data were collected using the observation method. To describe the parenting styles of students' parents / families in assisting kolok students in learning mathematics, data were collected using observation and interview methods.

In this research, the data analysis is using descriptive statistics, because it functions to describe or describe all the objects under study. In presenting the results of the analysis, we try to explore the data and present all the information that supports the results of the research conducted [7]. The method of analyzing / processing data is descriptive qualitative, namely arranging systematically in the form of sentences / words, categories, an object so that finally a general conclusion can be obtained [8]. Direct analysis of students' mathematics learning ability by doing (1) data reduction, namely selecting and sorting the data to be analyzed in the form of words, sentences or expressions according to the student's work using direct methods and indirect methods; (2) display data, namely the author displays the data that has been selected and sorted and analyzes it; (3) verification, namely the author concludes the results of the analysis [6].

\section{RESEARCH RESULT}

The students who used the research object were 2 class VI SD Negeri 2 Bengkala, Kubutambahan, Buleleng Regency. This school is a school that provides inclusive education. This school has 7 teachers, namely teachers in grades 1-6 and one special teacher who teaches children with special needs that are deaf and mute. There are 2 students with special needs, especially those who are mute or kolok at SD Negeri Bengkala, as many as 2 female students. Research population as well as research sample. All children who were used as research samples were students of class VI. This research was conducted for 2 months, from early August to September 2020. The kolok students were 2 people from Bengkala Village and one person from Nagasepeha Village. During the Covid-19 pandemic, students at SD Ngeri 2 carried out online learning. As of July 19th 2007,
SD Negeri 2 Bengkala began to hold inclusive education as a form of concern for the education of children with special needs in Bengkala Village. The idea of organizing inclusive education at SD Negeri 2 Bengkala originated from the school's concern about the education of deaf children with mute in Bengkala Village. The school wants learning together between deaf students and normal students. The school feels compelled to see deaf children who are mute so they can get an education like normal children. Until now, the education of kolok children in Bengkala Village has been going well. In fact, all kolok children in Bengkala Village receive a proper education.

Before Covid-19 hit Indonesia, students in the classroom were offline, mute and deaf children studied together with other normal students. The learning process that occurs is the same as learning in general, but special learning for kolok students is accompanied by a special teacher as a translator. Mr. I Made Wisnu Giri is a special teacher for deaf and mute children in class. During the learning process, the teacher will act as an intermediary / translator of information conveyed by the teacher through sign language. Thus, kolok students can understand what the teacher says. During the pandemic, kolok students did not combine learning with regular classes, because the learning process for regular classes was online. Online learning makes kolok students unable to mingle in forming groups with other normal children. In direct learning, kolok students and normal students study together, make assignments together and play together outside the classroom.

The exploration of Kolok Students' of Mathematical Abilities, since Covid-19 hit Indonesia and Bali in particular, learning was carried out online for students at SD Negeri 2 Bengkala. In this online learning between teachers and students do not meet directly, but teachers and students learn remotely using the media of a mobile phone (cellphone or laptop. For students who do not have a cellphone or cannot use a cellphone to support learning, the tasks are to The students are brought to the student's house by the teacher or the parents of the students who take them to school The time for the students to do homework for a week.

The ability of grade VI students is given basic fact questions of addition, subtraction, multiplication, and division. Problems that can be done are only the basic fact questions of addition, addition, multiplication, and division. In working on basic fact questions students still use simpoa's help, as shown in Figure 03. 

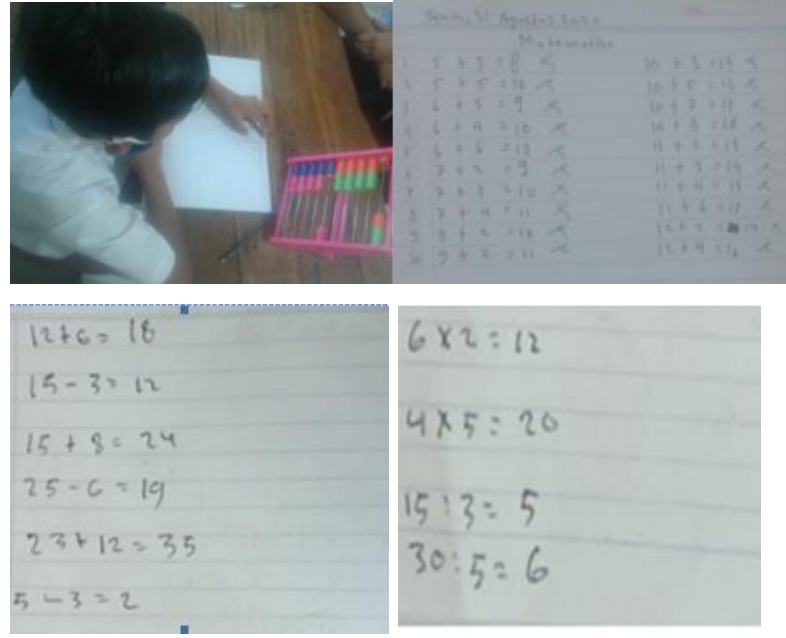

Figure 3 Students Doing Basic Fact Questions Using Simpoa's Help.

In solving division problems students use the set approach. As shown in the problem "12: $3=\ldots$. .", in solving this problem the students made three circles, each circle had four sticks, so the result of the division was 12: $3=4$. The same thing was done when working on the problem "30: $5=\ldots$ " as shown in Figure 04 below.

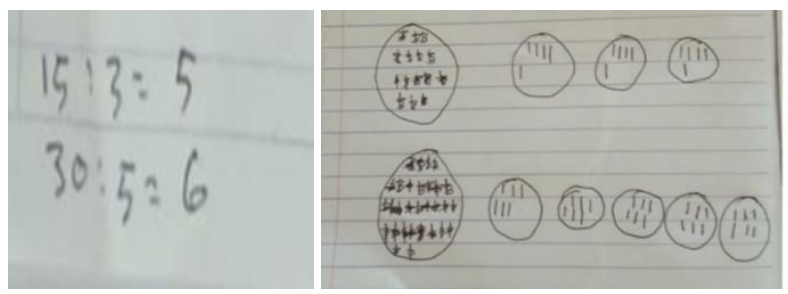

Figure 4 The Division Process using the assemblage Approach.

Students' ability in integer operations is very poor. Students have not been able to do addition, subtraction, multiplication, and division problems of integers. Students are still confused about working with positive numbers + negative numbers and negative numbers plus positive numbers as shown in the following example

$$
\begin{aligned}
& -3+5=10 \\
& 4+(-2)=7 \\
& 5-3=2 \\
& 2-7=4
\end{aligned}
$$

Likewise, for the subtraction of integers, students' abilities are very poor, as shown in Figure 05.

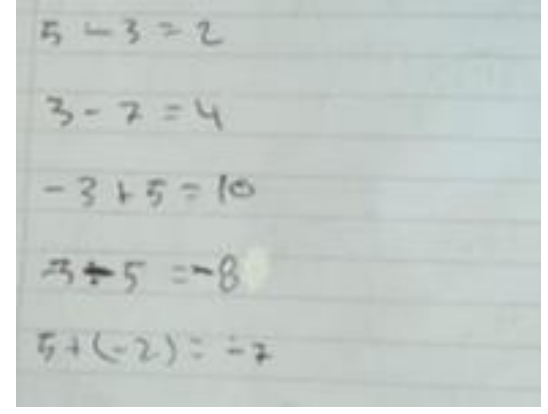

Figure 5 Students' answers to Addition and Subtraction of Integers.

The impact of students' weaknesses in the basic fact operations of addition, subtraction, multiplication, and division of integers is the difficulty of students working on questions with tens, hundreds, or thousands of numbers. Children with specific language impairment (SLI) have also shown marked difficulties in their ability to solve arithmetic problems correctly [9]. Likewise, in doing joint operations, students do not understand about solving joint operation problems because they do not understand which operations have a binding power greater than the four main operations. For example: in question $6+4: 2=$ students initially answered 10: $2=5$, but after it was explained that "the division operation was done first", then the students could answer correctly.

The students ability in operating simple fractions was also very lacking, all of the students' answers were wrong in answering fraction questions. Based on the students' answers, it seems that the students do not understand the concept of fractions. Students do not understand the numerator and denominator of a fraction.

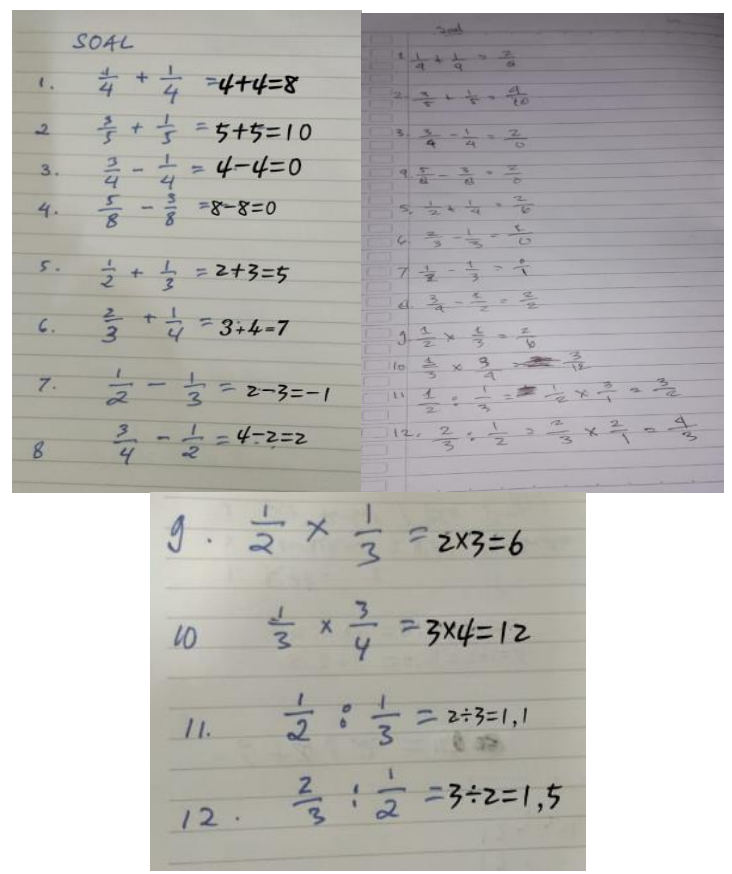

Figure 6 Results of the student work in Answering Fraction Questions. 
Constraints in the Learning Process, (1) students do not have cell phones, parents are not technologically literate, the cost of buying expensive quotas, signals are often interrupted, and it is difficult to control students in learning so that their character does not work well, (2) Teachers have difficulties in communicating with kolok students. This is generally experienced by children who come from areas outside the village of Bengkala. Besides that, the child is not used to being taught using sign language. This causes the teacher to have difficulty teaching at the first time or at the beginning of the student's entry to school at SD N 2 Bengkala, (3) the learning time that kolok students get at school is less than other normal students. This is because students learn depending on their interests and willingness. When they are bored, they will not want to continue learning, nor can the teacher force them to follow the learning process in class. So that these students will be given permission to do activities outside the classroom such as playing or just chatting with other students and their teachers, (4) Teachers who teach kolok students only have a high school diploma, so the ability to handle kolok students has difficulty. Difficulties experienced by teachers in implementing learning and mastery of mathematics material. The teacher is only able to communicate with students, and that too is learned by themselves.

The Teacher's Efforts to Overcome Constraints: (1) The teacher comes to the kolok student's house because they don't have a cellphone to study online, and gives assignments to do at home. The results of the student's work are again taken by the teacher to the student's house, (2) The teacher gives the students as free time as possible to organize their own learning. This is done because a kolok child cannot be forced in the learning process so that this special time provision provides space for them to develop their interests and talents in certain matters, (3) The teacher provides direction and guidance to kolok students when not in the learning process. such as directing students to the library to learn about sign language so that it is even easier to communicate with outsiders, (4) The teacher provides opportunities for kolok students to communicate with certain parties, for example with researchers in Bengkala village. This is done with the aim of training their courage in communicating with outsiders, (5) in the learning process regular teachers and special teachers teach kolok students teaching together in teams, so that they can complement each other in carrying out learning, and (6) the government should prepare teachers according to the needs of children with special needs, so that the handling of kolok students can be better. It could also be, existing teachers are given training to have adequate competence in handling special needs students at SD Negeri 2 Bengkala.

Interaction between normal students and kolok students, before the Covid-19 pandemic occurred, interaction between normal students and kolok students was the same as student interactions in general. When they take a break, they play together, shop at the canteen, exercise together even when they come home from school, they are always together to walk to their near home. Normal students are accustomed to interacting using sign language with either kolok friends or with the local community who have sign language skills. Based on interviews with normal students, they have no difficulty communicating with their friends. During this pandemic, communication and interaction between students is very rare. Interaction during learning also cannot be done, normally normal students and kolok students can study together at school, but now it cannot be done.

\section{CONCLUSION}

The ability of kolok students in mathematics especially in arithmetic is still lacking. This is evident from the ability of kolok students in the basic facts of basic operations that are still lacking. Students still use aids in working on basic fact questions. In integer operation, the students' ability is still lacking, as well as in whole number operations, during this pandemic, because of online learning, communication and interaction between students is very rare. Interaction during learning also cannot be done, usually normal students and kolok students can study together at school, but now this cannot be done, and the role of parents in helping students learn at home is very lacking, because the parents do not understand mathematics and Their IT skills are lacking, so they cannot help students study at home.

Suggestions that can be conveyed are (1) to deal with students with special needs, the government should prepare teachers who have the ability in the field of special needs students, and (2) Teachers in SD Negeri 2 Bengkala should be given special training in learning with special needs students.

\section{REFERENCES}

[1] A. M. Cross, L. M. D. Archibald, and M. F. Joanisse, Mathematical Abilities in Children with Developmental Language Disorder, Health and Rehabilitation Sciences Publications, 14, 2018. Available at: https://ir.lib.uwo.ca/hrspub/14.

[2] Hyde et al., Deaf and Hard of Hearing Students' Performance on Arithmetic Word Problems, American Annals of the Deaf, 148, 1: Academic Research Library, 2003.

[3] B. B. Fazio, Mathematical Abilities of Children with Specific Language Impairment, American SpeechLanguage-Hearing Association, Journal of Speech, Language, and Hearing Research, Vol. 39, 1996, pp. 839-849. 
[4] M. Efendi, Pendidikan Inklusif Sebagai Alternatif Layanan Pendidikan Bagi Anak Berkebutuhan Khusus, Kapita Selekta Ilmu Pendidikan, Pijar Pemikiran Tentang Konsep, Sistem, dan Masalahmasalah Pendidikan di Indonesia, Malang: Faklutas Ilmu Pendidikan Universitas Negeri Malang, 2019.

[5] Anafiah, Siti, Andini, Dinar Westri, Pelaksanaan Pendidikan Inklusi di SD Tumbuh 2 Yogyakarta, 2018.

[6] Emzir, Metodologi Penelitian Pendidikan Kuantitatif \& Kualitatif. Edisi Revisi, Jakarta: Rajawali Pers, 2012. https://pgsd.binus.ac.id/2017/04/10/pendidikaninklusi/

[7] I. Jaya, Penerapan Statistik Untuk Penelitian Pendidikan, Jakarta: Prenadamedia Group, 2019.

[8] A. A. G. Agung, Metodologi Penelitian Pendidikan, Singaraja: UNDIKSHA, 2014.

[9] Mainela-Arnold, et al., Knowledge of Mathematical Equivalence in Children with Specific Language Impairment: Insights from Gesture and Speech, National Library of Medicine, Lang Speech Hear Serv. Sch. 42(1) (2011) 18-30. 